\title{
E-Komik Pendidikan Untuk Membentuk Karakter Dan Meningkatkan Hasil Belajar Siswa Kelas V Pada Mata Pelajaran Bahasa Indonesia
}

\author{
Pande Made Weda Angga \\ Program Studi Teknologi Pendidikan, Universitas Pendidikan Ganesha \\ pande.made.weda@undiksha.ac.id \\ I Komang Sudarma \\ Program Studi Teknologi Pendidikan, Universitas Pendidikan Ganesha \\ ik-sudarma@undiksha.ac.id \\ I Kadek Suartama \\ Program Studi Teknologi Pendidikan, Universitas Pendidikan Ganesha \\ ik-suartama@undiksha.ac.id
}

\begin{tabular}{l} 
A R T I C L E I N F O \\
\hline Article history: \\
1 Juli 2020 Received in \\
revised form 30 Agustus \\
2020 \\
Accepted 28 Septemberl \\
2020 \\
Available online \\
30 September 2020 \\
\hline Kata Kunci: \\
Kata Kunci: \\
E-Komik Pendidikan, \\
Pendidikan Karakter \\
Keywords: \\
Educational E-Comics, \\
Character Education
\end{tabular}

\begin{abstract}
AB S T R A K
Kurangnya media pembelajaran khususnya pada mata pelajaran Bahasa Indonesia, guru maupun siswa hanya memanfaatkan buku yang disediakan oleh sekolah, oleh karna itu penelitian ini bertujuan untuk (1) membuat rancang bagun pengembangan media e-komik pendidikan untuk membentuk pendidikan karakter, (2) mengetahui validitas pengembangan media e-komik pendidikan untuk membentuk karakter. Subjek penelitian yaitu 2 ahli mata pelajaran, 1 ahli desain pembelajaran, 1 ahli media pembelajaran, 3 siswa untuk uji perorangan, dan 6 siswa untuk uji kelompok kecil. Metode dari pengumpulan data yang digunakan, yaitu: (1) kuisioner/angket, (2) wawancara (3) observasi. Rancang Bangun e-komik Pendidikan adalah meliputi 5 tahapan: tahap analisis (analysis), Tahap perancangan (design),
\end{abstract} Tahap pengembangan (development), Tahap implementasi (implementation), Tahap evaluasi (evaluation). (2) e-komik pendidikan ini valid dengan: (a) hasil review ahli isi mata pelajaran menunjukkan e-komik pendidikan berpredikat sangat tinggi $(1,00)$. (b) hasil review ahli desain pembelajaran menunjukkan bahwa e-komik pendidikan ini mendapatkan berpredikat yaitu baik $(81,66 \%)$ (c) hasil review dari ahli media pembelajaran menunjukkan e-komik pendidikan ini mendapatkan berpredikat baik (89\%). (d) hasil review dari uji perorangan menunjukkan e-komik pendidikan ini mendapatkan berpredikat sangat baik $(94,86 \%)$ (e) dan hasil review dari uji kelompok kecil menunjukkan e-komik pendidikan ini mendapatkan berpredikat baik $(89,99 \%)$. Dari hasil penelitian ini menunjukkan bahwa Ekomik pendidikan yang mengutamakan pendidikan karakter layak untuk diterapkan diharapkan dapat meningkatkan motivasi siswa dalam belajar, sehingga dapat meningkatkan hasil belajar siswa.

\footnotetext{
ABSTRACT

Lack of learning media, especially in Indonesian subjects, teachers and students only make use of books provided by schools, therefore this study aims to (1) design development of educational e-comic media to shape character education, (2) determine validity development of educational e-comic media to shape characters. The research subjects were 2 subject experts, 1 instructional design expert, 1 instructional media expert, 3 students for individual testing, and 6 students for small group testing. Methods of data collection used,
} 
namely: (1) questionnaire / questionnaire, (2) interview (3) observation. The design of educational e-comics includes 5 stages: the analysis stage, the design stage, the development stage, the implementation stage, the evaluation stage. (2) this educational ecomic is valid by: (a) the results of the subject content expert's review show that the educational e-comic has a very high predicate (1.00). (b) the results of the review by learning design experts show that this educational e-comic gets a good predicate $(81.66 \%)$ (c) the results of reviews from instructional media experts show that this educational ecomic gets a good predicate (89\%). (d) the results of the review from the individual test show that this educational e-comic gets a very good predicate $(94.86 \%)(e)$ and the review results from the small group test show that this educational e-comic gets a good predicate (89.99\%). The results of this study indicate that educational e-comics that prioritize character education are feasible to be applied, are expected to increase student motivation in learning, so as to improve student learning outcomes.

\section{PENDAHULUAN}

Kemajuan ilmu pengetahuan dan teknologi di era revolusi industri 4.0 menyebabkan teknologi sangat dibutuhkan pada segala aspek kehidupan manusia. (Jovanovski, dkk, 2019) menyatakan industri 4.0 merupakan revolusi industri baru yang berfokus pada digitaliasasi dan integrasi rangkaian nilai. Era revolusi industri 4.0 berdampak dalam dunia pendidikan. Smaldino, dkk (dalam Suartama, 2019:254) menyatakan bahwa teknologi berperan penting dalam dunia pendidikan tanpa terkeculi. Pemanfaat teknologi dalam proses pembelajaran sangat dibutuhkan pada saat ini. Menurut (Aprilia, dkk. 2019) Teknologi digunakan untuk menyelesaikan dan memecahkan masalah yang timbul dalam dunia Pendidikan.

Teknologi Pendidikan memiliki peranan penting dalam mengatasi masalah belajar, memumbuhkan minat belajar, dan mempermudah proses pembelajaran ( Sukayanti, dkk, 2018). Hal ini sesuai dengan definisi teknologi Pendidikan menurut Association for Educational Communication and Technology (AECT). ( dalam Mahadewi, 2015:9) menyatakan "Teknologi Pendidikan merupakan kajian dan praktik etika tentang memfasilitasi belajar dan meningkatkan kinerja dengan menciptakan, menggunakan, dan mengelola proses dan sumber teknologi yang tepat". Berdasarkan definisi tersebut dapat disimpulkan bahwa teknologi Pendidikan memiliki peran memecahkan masalah belajar. Permasalahan belajar dapat diatasi dengan menerapkan prinsip-prinsip teknologi pendidikan.

Keberhasilan suatu Negara dalam menghadapi revolusi industri 4.0, turut ditentukan oleh kualitas dari pendidik seperti guru. Menurut (Lase, 2019) menyatakan bahwa para guru dituntut menguasai keahlian, kemampuan beradaptasi dengan teknologi baru dan tantangan global. Keberhasilan kegiatan pembelajaran dapat diukur dengan keberhasilan siswa dalam memahami materi pembelajaran. Selain itu, salah satu aspek yang menentukan keberhasilan pembelajaran yaitu tersedianya fasilitas belajar seperti bahan ajar.

Bahan ajar merupakan faktor penting sebuah pembelajaran. Kurangnya bahan ajar tentu dapat mempengaruhi hasil pembelajaran. Depdiknas ( dalam Arsanti, 2019: 74 ) menyatakan, bahan ajar merupakan bahan yang digunakan guru dalam melaksanakan proses pembelajaran misalnya media audio, visual, maupun audio visual.

Bahan ajar dikelompokkan menjadi empat berdasarkan jeisnya yaitu (1) bahan cetak seperti handout, buku, dan modul, (2) bahan ajar audio seperti radio, (3) bahan ajar audio visual seperti video, dan (4) bahan ajar interaktif seperti Multimedia (dalam Arsanti, 2018). Bahan ajar akan bermanfaat dalam pembelajaran sehingga tujuan 
pembelajaran akan tercapai. Hal ini dibuktikan dengan hasil penelitian yang dilakukan oleh (Maslahah \& Rofiah, 2019) menyatakan bahwa penggunaan bahan ajar berupa modul dapat meningkatkan hasil belajar siswa. Penelitian yang dilakukan oleh (Prastowo, 2012) Handout bersumber dari beberapa literature yang relevan terhadap kompetensi dasar dan materi pokok yang diajarkan serta dapat memudahkan siswa dalam mengikuti proses pembelajaran. Berdasarkan penelitian tersebut dapat disimpulkan bahwa penggunaan bahan ajar dalam proses pembelajaran dapat meningkatkan hasil belajar siswa sehingga tujuan pembelajaran dapat berhasil.

Salah satu bahan ajar cetak yang menarik perhatian siswa adalah media komik. (Hidayah\& Rifky, 2017) menyatakan media komik adalah "bentuk kartun yang mengungkapkan karakter dan menerapkan suatu cerita dalam urutan yang erat hubungan nya dengan gambar dan dirancang untuk memberikan hiburan kepada pembaca". Keuntungan penggunaan komik adalah efisien waktu karena komik media yang dapat digunakan siswa secara berulang-ulang untuk belajar mandiri, dan mempermudah siswa memahami materi yang disampaikan Ati, dkk (dalam Witanta \& Inganah, 2019) .

Pemakaian komik dengan ilustrasi berwarna, alur cerita yang ringkas, perwatakan yang realitis akan menarik perhatian siswa (Lestari \& Projosantoso, 2016) Selain itu penelitian yang dilakukan oleh (Budiarti \& Haryanto, 2016) menyatakan bahwa media komik dapat meningkatkan motivasi dan ketrampilan membaca pemahaman siswa.(Daryanto, 2013) mengungkapkan bahwa komik sebagai bentuk kartun yang mengungkap-kan karakter dan menerapkan suatu cerita dalam urutan yang erat hubungannya dengan gambar dan dirancang untuk memberikan hiburan kepada pembaca. Berdasarkan penelitian tersebut, dapat disimpulkan bahwa media pembelajaran berbasis komik dapat meningkatkan minat, motivasi, dan pemahaman serta karakter sehingga hasil belajar siswa meningkat.

Berdasarkan hasil wawancara yang dilaksanakan pada tanggal 10 Oktober 2019, dengan walikelas $\mathrm{V}$ yang dilaksanakan di SD Negeri 7 Kampung Baru, diperoleh informasi bahwa pada saat kegiatan pembelajaran guru masih cenderung menggunakan metode ceramah. Kendala utama yang terdapat di SD Negeri 7 Kampung Baru yaitu media pembelajaran yang dimiliki masih kurang, khususnya pada mata pelajaran Bahasa Indonesia. Guru dan siswa hanya memanfaatkan buku pelajaran yang difasilitasi oleh sekolah. Selain itu, jam pelajaran yang sedikit dengan materi pembelajaran yang banyak membuat kesulitan guru dalam menyelesaikan materi pelajaran dengan tepat waktu.

Berdasarkan hasil observasi yang dilaksanakan di SD Negeri 7 Kampung Baru, didapatkan bahwa pada saat proses pembelajaran mata pelajaran Bahasa Indonesia, siswa kurang aktif saat proses pembelajaran. Selain itu, media pembelajaran yang digunakan guru hanya buku. Hasil analisis yang didapatkan pada nilai harian siswa pada mata pelajaran Bahasa Indonesia di SD Negeri 7 kampung Baru, masih tergolong relative rendah. Hal ini ditunjukan dari hasil analisis nilai ujian tengah semester siswa kelas $\mathrm{V}$,nilai rata-rata siswa yakni 60. Berdasarkan criteria ketuntasan minimal (KKN) rentangan nilai siswa yang mendapatkan rata-rata nilai yaitu 60 dinyatakan tidak lulus.

Hasil analisis penyebaran kuesioner mengenai pemilihan media yang disukai oleh siswa, didapatkan bahwa 90\% siswa kelas $\mathrm{V}$ memilih media komik dengan alasan siswa cenderung senang melihat gambar beserta teks yang singkat untuk memperjelas materi yang disampaikan oleh guru, dan memudahkan siswa dalam menyerap sebuah informasi. 
Berdasarkan permasalahan di atas, peneliti memandang perlunya media pembelajaran yang dapat membantu siswa dalam belajar, sehingga diperlukan media pembelajaran yang bersifat mandiri dan dapat membuat pembelajaran lebih menarik dan penggunaan kartun atau E-komik dalam pembelajaran juga mulai mendapatkan perhatian diantara pendidik karena meningkatkan pemahaman dan ketertarikkan, meningkatkan motivasi untuk belajar, memperbaiki perilaku, meningkatkan produktivitas dan kreativitas, mengurangi stress dan kegelisahan, meningkatkan keaktifan partisipasi siswa dalam proses pembelajaran, dan dapat mengurangi kebosanan (Purnamasari, dkk., 2018). Pengembangan media E-komik pendidikan untuk meningkatkan hasil belajar siswa kelas V di SD Negeri 7 Kampung Baru, khususnya mata pelajaran Bahasa Indonesia. Dari peneliti (Listiyani \& Widayati, 2012) menyatakan bahwa media E-komik dapat mendorong siswa untuk menambah rasa ingin tahu, wawasan, dan pengetahuan. Penyajian materi dipadukan dengan cerita bergambar dengan tema pendidikan, yang dapat menarik minat baca siswa kelas V di SD Negeri 7 Kampung Baru. Pengembangan komik ini diharapkan dapat memfasilitasi siswa dalam belajar, sehingga dapat mengasah kemampuan diri khususnya dalam pembelajaran Bahasa Indonesia.

\section{METODE PENELITIAN}

Penelitian pengembangan ini dilaksankan pada tanggal 04 April 2019 sampai 10 Januari 2020. Subjek dari penelitian ini yaitu 2 ahli isi mata pelajaran, 1 ahli desain pembelajaran, 1 ahli media pembelajaran, 3 uji perorangan dan 6 uji ahli kelompok kecil Pada penelitian pengembangan ini menggunakan tiga metode dalam pengumpulan data yaitu: (1) metode observasi, (2) metode wawancara, dan (3) metode kuesioner/angket. Pemilihan model Penelitian pengembangan ADDIE didasarkan karena model penelitian pengembangan ADDIE adalah salah satu model desain sistem pembelajaran yang memperlihatkan tahapan-tahapan dasar desain sistem pembelajaran yang sederhana dan mudah dipelajari serta tersistematis. Prastya, dkk (2015) menyatakan tahapan model ADDIE terdiri atas lima tahapan yaitu: "analisis (analyze), desain (design), pengembangan (development), implementasi (implementation), dan evaluasi (evaluation)". Pemilihan model ini didasari atas pertimbangan karena model ini memiliki tahapan yang sistematis dan mudah dipahami dan berpijak pada landasan teoritis desain pembelajaran.

Instrumen yang dikembangkan meliputi instrumen ahli mata pelajaran, instrumen ahli desain pembelajaran, instrumen ahli media pembelajaran, dan instrumen uji coba perorangan dan kelompok kecil. Setelah instrument di-review oleh pakar selanjutnya didapatkan validitas isi yang dianalisis menggunakan rumus Gregoy. Adapun kisi-kisi mata pelajaran, ahli desain pembelajaran, ahli media pembelajaran, dan uji coba perorangan atau kelompok kecil dijabarkan pada tabel 2,3,4 dan tabel 5 .

Tabel 1. Kisi-kisi Instrumen Ahli Mata Pelajaran

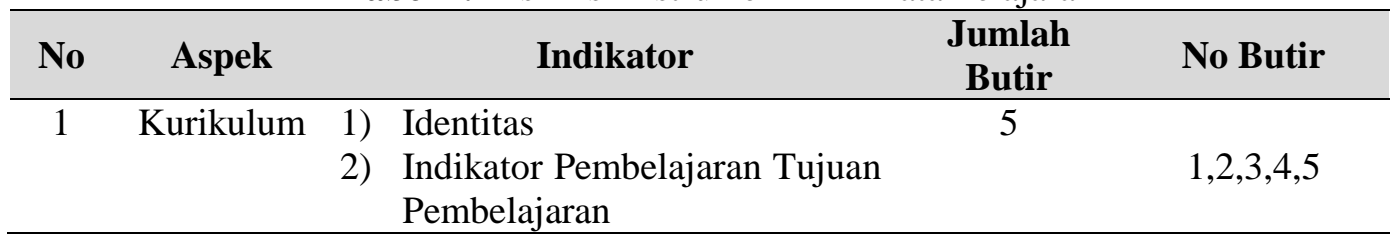




\begin{tabular}{|c|c|c|c|c|c|}
\hline 2 & Materi & 1) & $\begin{array}{l}\text { Kesesuaian isi materi } \\
\text { Sistematika materi Tingkat } \\
\text { kemudahan dan kedalaman } \\
\text { materi }\end{array}$ & 6 & $6,7,8,9,10,11$ \\
\hline 3 & Bahasa & $\begin{array}{l}\text { 1) } \\
\text { 2) } \\
\text { 3) }\end{array}$ & $\begin{array}{l}\text { Kejelasan informasi } \\
\text { Penggunaan bahasa } \\
\text { Penggunaan tanda baca } \\
\text { Keterbacaan }\end{array}$ & 5 & $12,13,14,15,16$ \\
\hline 4 & Evaluasi & 1) & $\begin{array}{l}\text { Tingkat kesulitan } \\
\text { Kejelasan rumusan soal }\end{array}$ & 3 & $17,18,19$ \\
\hline
\end{tabular}

Berdasarkan tabel diatas, aspek yang terdapat pada instrumen ahli mata pelajaran meliputi kurikulum, materi, bahasa, dan evaluasi. Instrumen ini terdiri dari 19 butir pernyataan yang dinilai oleh ahli mata pelajaran mengenai E-komik pendidikan yang telah dikembangkan. Selanjutnya kisi-kisi instrumen ahli desain pembelajaran akan dipaparkan pada tabel 2 yaitu sebagai berikut.

Tabel 2. Kisi-kisi Instrumen Ahli Desain Pembelajaran

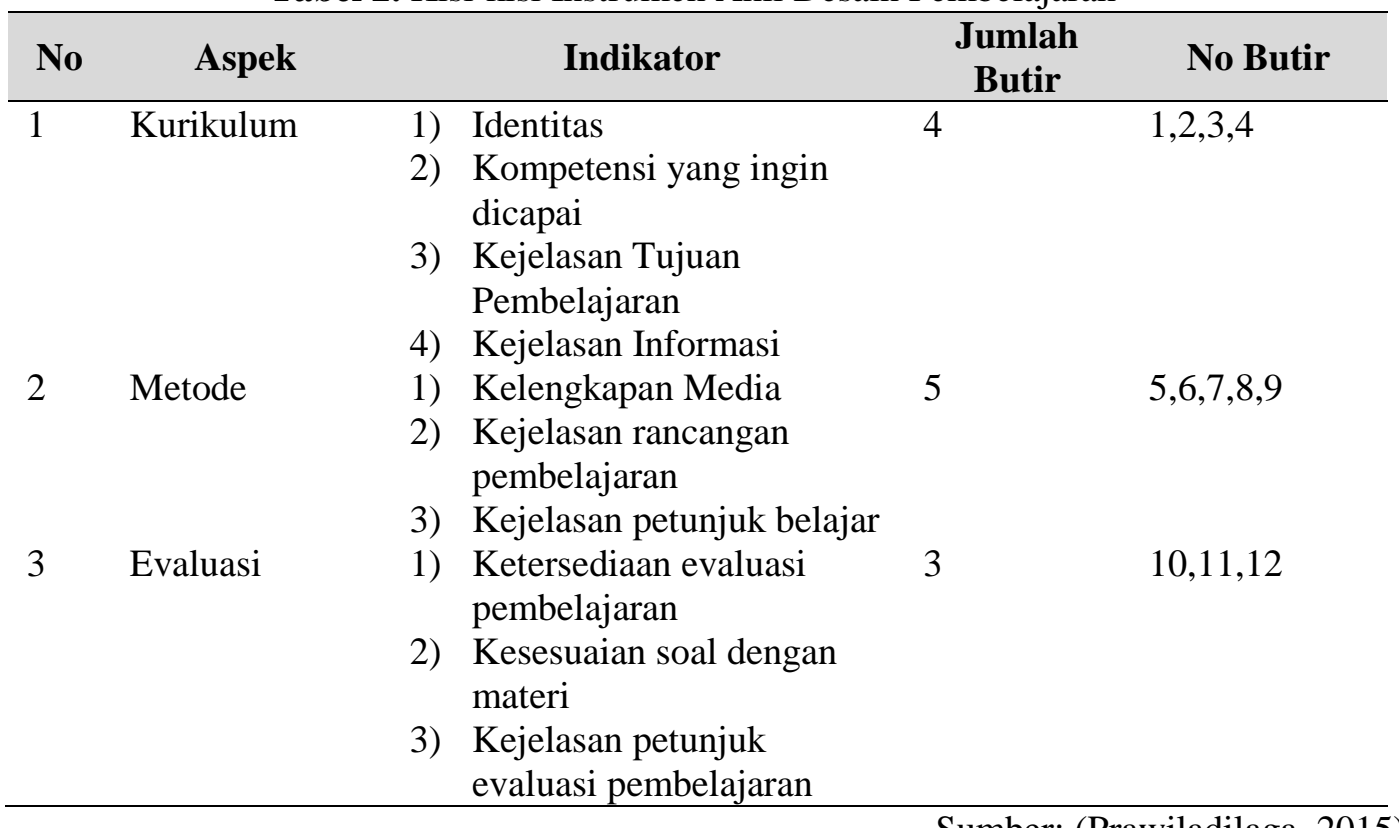

Berdasarkan tabel diatas, aspek yang terdapat pada instrumen ahli desain pembelajaran meliputi kurikulum, metode, dan evaluasi. Instrumen ini terdiri dari 12 butir pernyataan yang dinilai oleh ahli mata desain pembelajaran mengenai E-komik pendidikan yang telah dikembangkan. Selanjutnya kisi-kisi instrumen ahli media pembelajaran akan dipaparkan pada tabel 3 yaitu sebagai berikut.

Tabel 3. Kisi-kisi Instrumen Ahli Media Pembelajaran

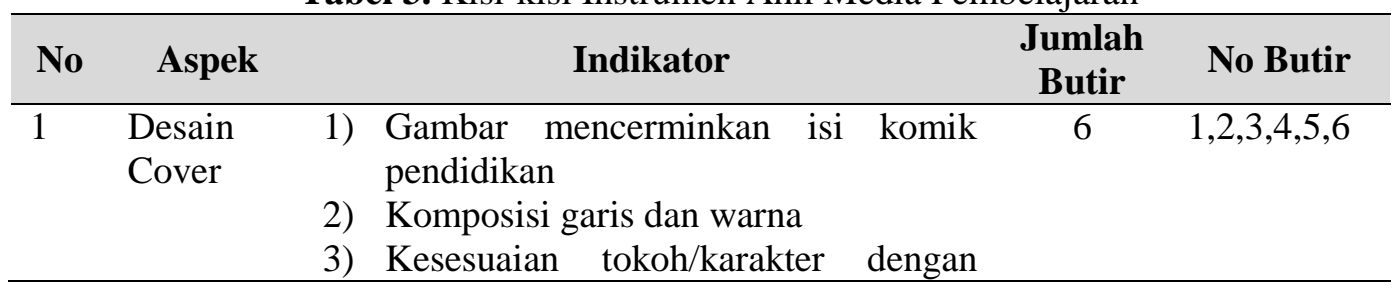




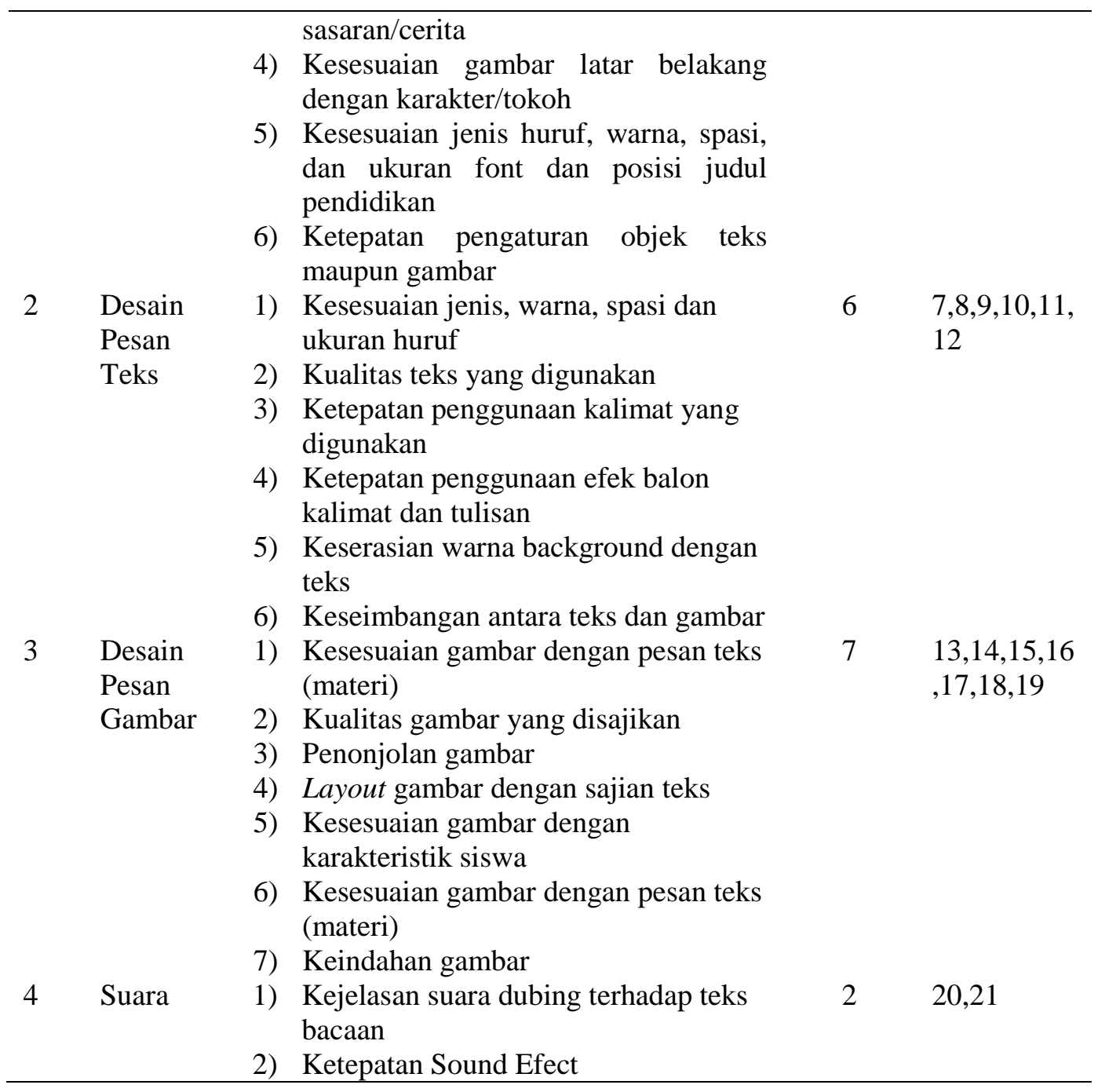

Berdasarkan tabel diatas, aspek yang terdapat pada instrumen ahli media pembelajaran meliputi desain cover, desain pesan teks, desain pesan gambar, dan suara. Instrumen ini terdiri dari 21 butir pernyataan yang dinilai oleh ahli mata desain pembelajaran mengenai E-komik pendidikan yang telah dikembangkan. Selanjutnya kisikisi instrumen untuk uji coba perorangan dan kelompok kecil akan dipaparkan pada tabel 4 yaitu sebagai berikut.

Tabel 4. Kisi-kisi Instrumen Uji Coba Perorangan dan Kelompok Kecil

\begin{tabular}{|c|c|c|c|c|}
\hline No & Aspek & Indikator & $\begin{array}{c}\text { Jumlah } \\
\text { Butir }\end{array}$ & No Butir \\
\hline 1 & $\begin{array}{l}\text { Media } \\
\text { Pembelajaran }\end{array}$ & $\begin{array}{l}\text { 1) Kemudahan Penggunaan } \\
\text { 2) Kemenarikan } \\
\text { 3) Ketepatan media } \\
\text { pembelajaran }\end{array}$ & 4 & $1,2,3,4$ \\
\hline 2 & Materi & $\begin{array}{l}\text { 1) Ketepatan isi materi } \\
\text { 2) Bahasa } \\
\text { 3) Evaluasi }\end{array}$ & 6 & $5,6,7,8,9,10,11$ \\
\hline 3 & Manfaat & $\begin{array}{l}\text { 1) Ketertarikan } \\
\text { 2) Motivasi belajar }\end{array}$ & 2 & 12,13 \\
\hline
\end{tabular}


Berdasarkan tabel diatas, aspek yang terdapat pada instrumen uji coba perorangan dan kelompok kecil meliputi media pembelajaran, materi, dan manfaat. Instrumen ini terdiri dari 13 butir pernyataan.

Metode analisis data yang digunakan pada penelitian pengembangan ini adalah metode analisis deskriptif kualitatif, dan metode deskriptif kuantitatif. Metode ini digunakan untuk mengolah data dari hasil ahli mata pelajaran, ahli desain pembelajaran, ahli media pembelajaran, dan ahli uji coba perorangan dan kelompok kecil. Dalam mengambil keputusan mengenai kualifikasi media E-komik digunakan konversi tingkat pencapaian skala 5 yang dipaparkan pada tabel 5 .

Tabel.5 Konversi Tingkat Pencapaian dengan Skala 5

\begin{tabular}{ccc}
\hline Tingkat & Kualifikasi & Keterangan \\
Pencapaian & Sangat baik & Tidak perlu direvisi \\
$90 \%-100 \%$ & Baik & Sedikit direvisi \\
$75 \%-89 \%$ & Cukup & Direvisi secukupnya \\
$65 \%-74 \%$ & Kurang & Banyak hal yang direvisi \\
$55 \%-64 \%$ & Sangat Kurang & Diulangi membuat produk \\
$0-54 \%$ & & $($ Sum
\end{tabular}

(Sumber: :Tegeh dan Jampel, 2017:223)

\section{HASIL DAN PEMBAHASAN}

\section{HASIL}

Hasil penelitian ini akan dibahas menjadi dua hal pokok adalah: mendeskripsikan rancang bangun pembelajaran media E-komik, dan mendeskripsikan validitas pengembangan media E-komik. Rancang bangun media E-komik ini menggunakan model pengembangan ADDIE. Pengembangan E-komik ini dimulai pada tahap analisis. Hasil dari kegiatan analisis yang telah dilakukan adalah: (1) analisis karkteristik siswa dan masalah dalam pembelajaran seperti halnya: guru menjadi pusat sumber belajar dan hanya menggunakan metode ceramah, lalu siswa akan cepat merasa bosan pada saat proses pembelajaran jika menggunakan metode ceramah terus menerus dan terbatasnya media yang sifatnya interaktif serta kebanyakan media bersifat cetak contohnya seperti buku pelajaran, buku cerita dan lain-lain hasil yang didapatkan, jadi media yang cocok dalam mengatasi permasalahan diatas yaitu E-komik pendidikan, (2) analisis kompetensi seperti menetapka Kompetensi Inti, Kompetensi Dasar, dan Indikator dan (3) anlisis fasilitas dan ketersediaan sumber belajar, sebagian besar siswanya sudah bisa mengoperasikan smartfhone maupun leptop. Fasilitas yang dimiliki oleh SD Negeri 7 Kampung Baru juga sudah cukup mendukung seperti halnya sudah terdapat sarana pembelajaran, seperti LCD, Layar Proyektor serta akses Internet.

Tahap kedua adalah desain pada tahap ini dilakukan pembuatan peta konsep Ekomik, kerangka E-komik, dan storyboard dan flowchart pada media E-komik, serta penyusunan instrumen. Peta konsep digunakan untuk mengetahui gambaran secara umum dari E-komik tersebut, kerangka ini digunakan untuk penyusunan materi dan konten yang digunakan dalam pengembangan E-komik, flowchart digunakan sebagai gambaran alur kerja dari E-komik tersebut dan storyboard digunakan sebagai alur dari gagasan pengembangan media E-komik, serta penyusunan instrument digunakan untuk mengetahui validitas dari produk yang sudah dikembangkan. 
Tahap ketiga adalah pengembangan. Pada tahap ini kegiatan yang dilakukan yaitu (1) pembuatan karakter pada tahap ini proses pembuatan karakter E-komik ini dengan secara manual menggunaka kertas dan pensil, setelah itu di scan untuk memasukan gambar ke dalam leptop kemudian mengambar di leptop dalam membuat E-komik ini, (2) menggabungkan gambar di Corel Draw $x 7$ pada tahap ini karakter yang sudah selesai digamba, proses gambar background pada E-komik menggunakan aplikasi Corel Draw $x$ 7 sebagai aplikasi utama (3) finishing menggunakan aplikasi Microsoft Power Point 2010 pada tahap ini proses finishing terdiri dari memasukkan dabing atau backsound ke dalam gambar menggunakan Microsoft Power Point dan akan di fablish dalam bentuk format HTML.

Tahap keempat yaitu implementasi. Pada tahap ini kegiatan yang dilakukan (1) uji validasi media E-komik yang berdasarkan aspek dari isi mata pelajaran Bahasa Indonesia oleh ahli mata pelajaran Bahasa Indonesia, (2) uji validasi E-komik berdasarkan aspek desain oleh ahli desain pembelajaran, (3) uji validasi media E-komik berdasarkan aspek oleh ahli media pembelajaran, (4) uji coba perorangan, yang berujuan untuk mengetahui kelayakan dan kualitas dari media E-komik ini yang dikembangkan.

Dan tahap terakhir adalah evaluasi. Tahap ini merupakan tahap terakhir melakukan evaluasi data yang sudah terkumpul pada tahap implementasi. Evaluasi berupa formatif. Evaluasi formatif bertujuan untuk menilai produk yang sudah dikembangkan yang mencakup validitas ahli, dan uji coba perorangan dan kelompok kecil. Berdasarkan tahapan tersebut maka E-komik pendidikan ini berhasil dikembangan dengan model ADDIE.

Uji validitas E-komik pendidikan ini bertujuan untuk menguji tingkat kelayakan dari sebuah media E-komik dengan model ADDIE. Instrument pengembangan E-komik pendidikan ini berupa kuesioner yang sebelumnya sudah dipersiapkan dalam bertujuan untuk mengetahui validitas sebuah produk. Instrument tersebut terlebih dahulu diujikan validitas butirnya oleh orang judges yang berkompeten dibidangnya. Adapun hasl dari validasi instrument yang telah diuji, dipaparkan pada tabel 6 .

Tabel 6. Hasil dari Uji Validitas Instrument

\begin{tabular}{ccc}
\hline Jenis Validitas & Hasil & Kualifikasi \\
\hline Validitas Isi & 1 & Sangat Tinggi \\
Validitas Desain & 1 & Sangat Tinggi \\
\hline Validitas Media & 1 & Sangat Tinggi \\
\hline
\end{tabular}

Hasil dari validitas instrument dari isi mata pelajaran oleh judges mendapatkan nilai 1, sehingga termasuk dalam kriteria validitas sangat tinggi. Hasil dari validitas instrument desain pembelajaran mendapatkan nilai 1, sehingga termasuk dalam kriteria sangat tinggi, dan dari hasil validitas media pembelajaran E-komik pendidikan juga mendapatkan kualifikasi sangat tinggi. Setelah dilakukan uji validitas instrument, setelah itu dilanjutkan dengan penilaian dari para ahli (ahli isi mata pelajaran, ahli desain pembelajaran, ahli media pembelajaran) terhap produk yang dikembangkan oleh peneliti. Adapun hasil tersebut secara rinci dipaparkan pada tabel 7. 
Tabel 7 Hasil Uji Validitas Produk

\begin{tabular}{clcc}
\hline No & Subjek Uji Coba E-Komik & $\begin{array}{c}\text { Hasil Validitas } \\
(\mathbf{\%})\end{array}$ & Keterangan \\
& & 1,00 & Sangat Tinggi \\
2 & Uji Ahli Isi Mata Pelajaran & $81,66 \%$ & Baik \\
3 & Uji Ahli Desain Pembelajaran & $89 \%^{\circ}$ & Baik \\
4 & Uji Coba Perorangan & $94,85 \%$ & Sangat Baik \\
5 & Uji Coba Kelompok Kecil & $89,99 \%$ & Baik \\
\hline
\end{tabular}

Berdasarkan dari pengujian yang sudah dilakukan oleh ahli isi mata pelajaran Bahasa Indonesia dengan menggunakan metode pengumpulan data kuesioner serta instrument yang digunakan adalah lembar kuesioner. Didapatkan bahwa hasil dari perhitungan yang sudah dikonversi pada tingkat pencapaian skala 5 , persentase yaitu $1,00 \%$, sehingga mendapatkan kualifikasi sangat tinggi.

Pengujian yang sudah dilakukan oleh ahli desain pembelajaran, dengan menggunakan metode pengumpulan data kuesioner dan instrument yang digunakan adalah lembar kuesioner. Didapatkan hasil perhitungan yang sudah dikonversi pada tingkat pencapaian skala 5 , dengan persentase pencapaian yaitu $81 \%$, sehingga mendapatkan kualifikasi baik.

Pengujian yang sudah dilakukan oleh ahli media pembelajaran, dengan menggunakan metode pengumpulan data kuesioner dan instrument yang digunakan adalah lembar kuesioner. Didapatkan hasil perhitungan yang telah dikonversi pada tingkat pencapaian skala 5, persentase pencapaian adalah $89 \%$, sehingga mendapatkan kualifikasi sangat baik. Berdasarkan pengujian yang sudah dilakukan oleh uji coba perorangan yang dilakukan oleh 3 (tiga) orang siswa kelas VI SD 1 Paket Agung diperoleh persentase tingkat pencapaian sebesar 94,85\%, sehingga mendapatkan kualifikasi sangat baik. Dan berdasarkan pengujian yang sudah dilakukan oleh uji kelompok kecil yang dilakukan oleh 6 (enam) orang siswa kelas VI SD 1 Paket Agung diperoleh persentase tingkat pencapaian sebesar $89,99 \%$ mendapatkan kualifikasi baik.

Dari perolehan hasil tersebut, maka dapat disimpulkan bahwa E-komik pendidikan layak untuk diterapkan dan perlunya direvisi berdasarkan masukan yang diberikan oleh ahli desain dan ahli media pembelajaran, masukan yang diberikan dipertimbangkan dan digunakan untuk menyempurnakan E-komik pendidikan. Adapun hasil revisi produk Ekomik pendidikan ini dapat disajikan sebagai berikut.

Tabel 8. Perbaikan Produk Ahli Desain Pembelajaran

\begin{tabular}{clll}
\hline No & \multicolumn{1}{c}{ Masukan, Saran dan Komentar } & \multicolumn{1}{c}{ Revisi } \\
\hline 1 & $\begin{array}{l}\text { Pada halaman Depan isi kelas, Semester, dan } \\
\text { tempat judul pada tengah-tengah halaman }\end{array}$ & $\begin{array}{l}\text { Menambahkan pada Cover } \\
\text { berisikan Kelas dan Semester. } \\
\text { Pada tempat judul pada } \\
\text { tengah-tengah halaman }\end{array}$ \\
2 & Ada kesalahan ketik pada rumusan tujuan & $\begin{array}{l}\text { Memperbaiki kesalahan ketik } \\
\text { pada rumusan tujuan }\end{array}$ \\
3 & $\begin{array}{l}\text { Pada bagian awal perkenalkan nama masing- } \\
\text { Masing karakter }\end{array}$ & $\begin{array}{l}\text { Menambahkan pada awal } \\
\text { berisikan perkenalkan nama } \\
\text { karakter masing-masing }\end{array}$ \\
4 & $\begin{array}{l}\text { Pada bagian ini agar karakter saling } \\
\text { berhadapan-hadapan yang mevisualisasikan }\end{array}$ & $\begin{array}{l}\text { Pada gambar disamping } \\
\text { merubah posisi karakter agar }\end{array}$ \\
\hline
\end{tabular}




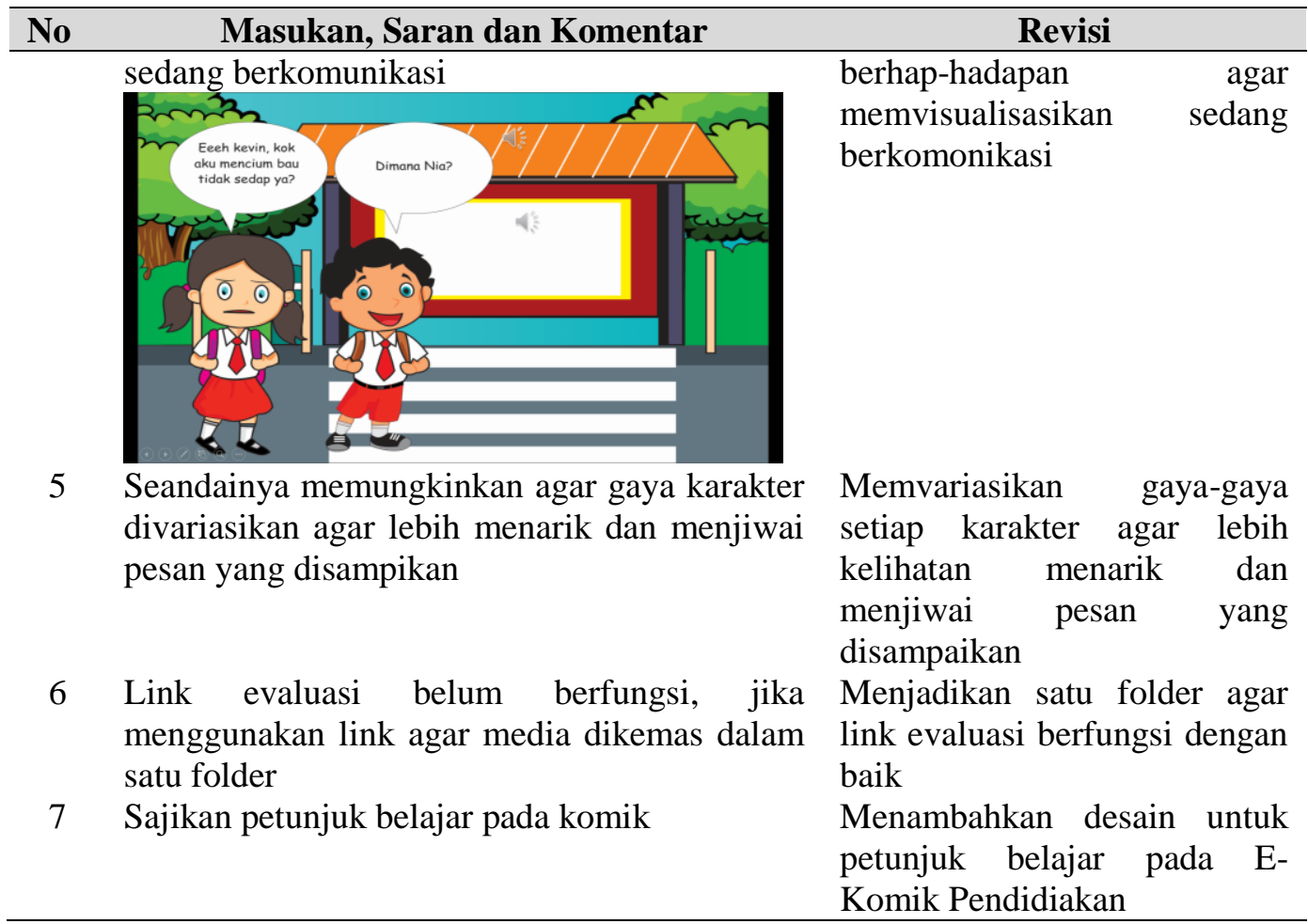

Berdasarkan masukan dan saran yang sudah diberikan oleh ahli media pembelajaran, maka perlu dilakukan perbaikan demi penyempurnaan produk yang dikembangkan. Adapun revisi produk E-komik pendidikan disajikan pada tabel 9.

Tabel 9. Perbaikan Produk Ahli Media Pembelajaran

\begin{tabular}{cll}
\hline No & \multicolumn{1}{c}{ Masukan, Saran dan Komer } & \multicolumn{1}{c}{ Revisi } \\
1 & $\begin{array}{l}\text { Desain dari awal E-komik pada bagian } \\
\text { KD, Tujuan Pembelajaran direvisi }\end{array}$ & $\begin{array}{l}\text { Merubah tampian pada aspek desain } \\
\text { di awal pembelajaran yakni pada } \\
\text { KD, Tujuan Pembelajaran }\end{array}$ \\
2 & $\begin{array}{l}\text { Perbaiki gambar disamakan dengan } \\
\text { ekspresi wajah }\end{array}$ & $\begin{array}{l}\text { Memperbaik scan pada ekspresi } \\
\text { wajah pada karakter, sesuaikan } \\
\text { dengan suasana pada scan tersebut }\end{array}$ \\
3 & $\begin{array}{l}\text { Perbaiki pemenggalan kata dalam satu } \\
\text { kalimat }\end{array}$ & $\begin{array}{l}\text { Memperbaiki dari aspek } \\
\text { pemenggalan kata pada dialog dari } \\
\text { karakter, jika ada satu kata yang } \\
\text { tercecer maka dijadikan satu kalimat } \\
\end{array}$ \\
& saja \\
\hline
\end{tabular}

Adapun hasil pengembangan produk E-komik pendidikan pada mata pelajaran Bahasa Indonesia disajikan pada gambar 1, 2, dan 3.

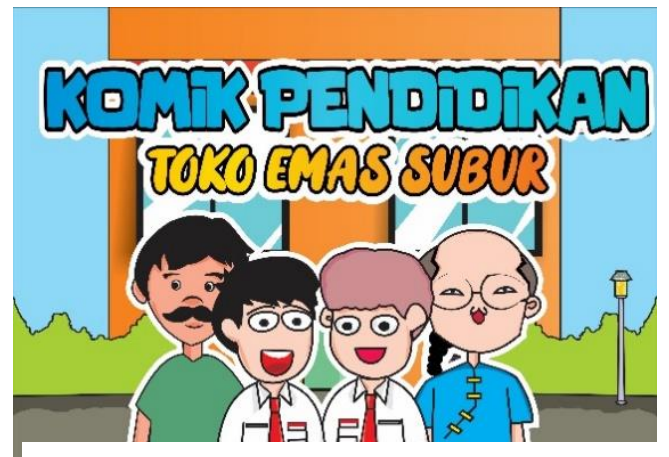

Gambar 1. Halaman Cover

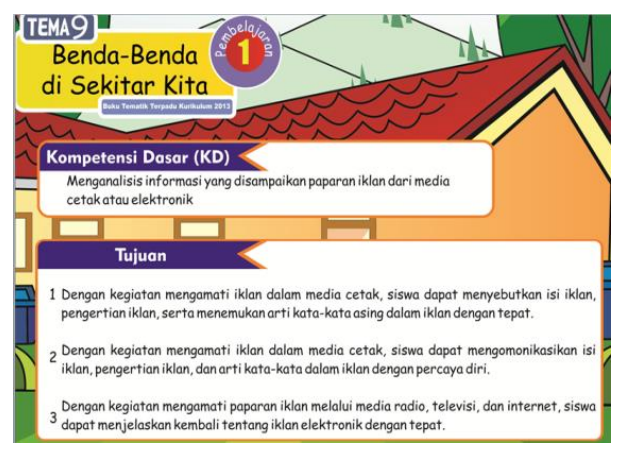

Gambar 2. Halaman Kompetensi 


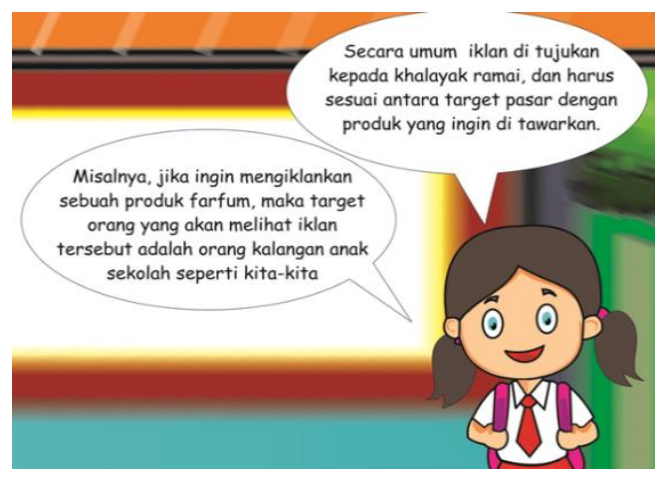

Gambar 3. Halaman Materi

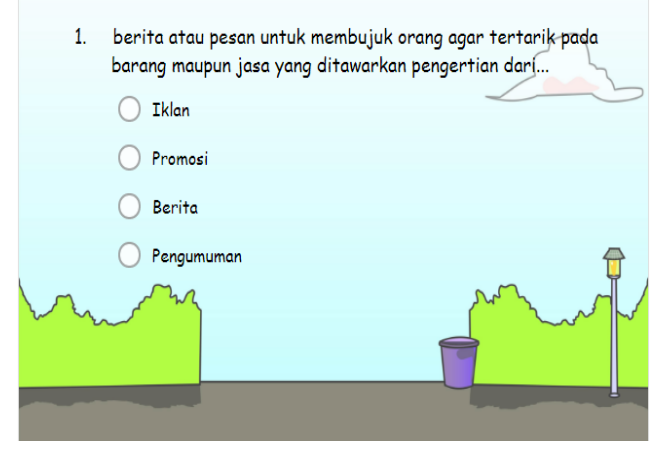

Gambar 4. Halaman Evaluasi

\section{PEMBAHASAN}

E-Komik pendidikan membentuk karakter yang dikembangkan dalam peneletian ini bertujuan untuk, agar siswa dapat meningkatkan hasil belajar yang baik serta meningkatkan motivasi belajar siswa, kemudian dapat mempermudah guru dalam mengembangkan kegiatan pembelajaran serta mengelola kelas. Hasil penelitian ini menunjukkan bahwa E-komik pendidikan membentuk karakter yang dikembangkan telah melalui serangkaian tahap pengembangan dan telah divalidasi oleh para ahli dibidangnya masing-masing serta telah diuji cobakan. Dalam pengembangannya E-komik pendidikan ini telah dinyatakan berpengaruh terhadap hasil belajar siswa pada pembelajaran Bahasa Indonesia.

Penelitian pengembangan E-Komik Pendidikan pada materi mengenal apa itu Iklan untuk siswa kelas V semester genap di SD Negeri 7 Kampung Baru. Untuk langkahlangkah dari pengembangan E-komik ini sesuai dengan model yang diterapkan yaitu model ADDIE 1) Tahap Analysis (Analisis), (2) Tahap Design (Perancangan), (3) Tahap Depelovment (Pengembangan), (4) Tahap Implementation (Implementasi), dan (5) Tahap Evaluation (Evaluasi). Model ADDIE ini digunakan karna prosedur dan langkahlangkahnya yang dilalui dalam pengembangan produk ini sangat mudah dan jelas serta sistematis sehingga sesuai dengan desain pembelajaran yang dikembangkan. Hal ini sejalan dengan pendapat ahli dari (Tegeh \& Kirna, 2013) yang menyatakan bahwa model ADDIE merupakan model desain pembelajaran yang paling generik dan dikembangkan dengan secara sistematis serta berpijak pada landasan teoritis pada desain pembelajaran. Pertimbangan yang harus di perhatikan dalam menentukan model pengembangan yang akan digunakan dalam proses pemebuatan produk diantarnya adalah: (1) model yang dipilih haruslah dipahami oleh pengembang, (2) tahapan mengandung yang tidak perlu kompleks juga tidak terlalu sederhana, dan (3) model dapat mengarahkan pengembang membuat program secara lebih aktif (dalam Mahadewi dan Sukmana, 2015:87)

Hasil review ahli isi pembelajaran, menunjukkan bahwa E-komik pendidikan memperoleh validasi sebesar 1,00 yang berada pada kriteria sangat tinggi. Kriteria sangat tinggi ini diperoleh karena pada review ahli isi pembelajaran terhadap butir instrumen kesesuaian kompetensi dasar atau tujuan pembelajaran berada pada validitas sangat tinggi yaitu dengan tingkat pencapaian 1,00. Kesesuaian E-komik pendidikan dengan tujuan pembelajaran, dan kesesuaian kompetensi dasar atau tujuan pembelajaran hal ini juga dapat dibuktikan dengan hasil kuesioner yang disebarkan kepada siswa pada butir instrument terkait materi yang disediakan dalam E-komik sesuai dengan tujuan pembelajaran diperoleh $(94,86 \%)$ dengan kriteria sangat baik pada uji coba perorangan, 
sedangkan kriteria baik $(89,99 \%)$ pada uji kelompok kecil. Jadi dapat disimpulkan bahwa kesesuaian E-komik pembelajaran dengan tujuan pembelajaran sudah sesuai. Hal ini sejalan dengan pernyataan Alessi \& Trollip (dalam Yogiyatno, 2013:396) menyatakan bahwa keefektifan pembelajaran didefinisikan sebagai terwujudnya hasil pembelajaran sesuai dengan tujuan pembelajaran yang telah ditetapkan. Rossi dan Breidle (dalam Wina Sanjaya, 2010:204) menyatakan bahwa pemilihan media pembelajaran telah disesuaikan dengan tujuan pembelajaran yang hendak dicapai. Menjadi seorang tenaga pendidik haruslah senantiasa memilih media pembelajaran yang didasarkan pada tujuan yang akan dicapai.

Dari hasil review ahli media pembelajaran, menunjukkan bahwa teks dan gambar pada media E-komik ini berada pada kualifikasi sangat baik, yakni 89\%. Kriteria ini baik karna diproleh pada butir instrumen tentang keseimbangan antara teks dan gambar yang mendukung dan memperjelas dari isi materi yang dijelaskan memperoleh penilaian sangat baik yaitu $90 \%$. pada uji ahli isi pembelajaran, keseimbangan antara teks dan gambar ini juga dibuktikan dengan hasil kuesioner yang disebarkan kepada siswa pada butir instrumen yang terkait kemenarikan gambar dan alur cerita sangat menarik diperoleh $(94,86)$ dengan kriteria sangat baik pada uji perorangan, dan kriteria baik (89.99) pada uji kelompok kecil. Jadi dapat disimpulkan bahwa keseimbangan gambar dan teks untuk memperjelas materi sudah sesuai. Jadi dapat disimpulkan bahwa keseimbangan antara teks dan gambar yang mendukung dan memperjelas dari isi materi yang dijelaskan, keindahan gambar, dan kejelasan dubing atau soundefect sangat baik. Hal ini sejalan dengan pendapat Sudarma, dkk (2015:6) yang menyatakan bahwa suara dalam komunikasi media seperti suara dubing, suara efek, dan suara latar merupakan elemen pendukung kejelasan pesan pada gambar atau video untuk dapat memberikan kesan penekanan, senang, sedih dan lain-lain. Dan sejalan dengan pendapat dari (Fleming \& Levie, 1993) menyatakan bahwa teks dapat dibedakan menjadi teks tertulis (visual) dan teks lisan (audio). Begitu juga dengan gambar dapat dibedakan menjadi gambar diam atau gambar bergerak contohnya seperti video dan animasi.

Hasil dari review ahli desain pembelajaran, menunjukkan bahwa kesesuian urutan penyajian materi pembelajaran berada pada kualifikasi baik, yakni $81 \%$. Perolehan kriteria baik ini karena pada butir terkait kesesuian urutan penyajian materi pembelajaran, kejelasan dari kecukupan dukungan bahan ajar dalam E-komik berada pada kriteria sangat baik $90 \%$. Sedangkan penilaian yang oleh siswa pada butir instrumen yang terkait dari isi kesesuian urutan penyajian materi pembelajaran diperoleh $(94,86)$ dengan kriteria sangat baik pada uji perorangan, dan kriteria baik (89.99) pada uji kelompok kecil. Jadi dapat disimpulkan bahwa kesesuian urutan penyajian materi pembelajaran, kejelasan dari kecukupan dukungan bahan ajar, hal ini sejalan dengan pendapat Sanjaya (2008) menyatakan bahwa desain pembelajaran berkenaan dengan proses menentukan tujuan pembelajaran, strategi dan teknik untuk mencapai tujuan serta merancang media yang dapat digunakan untuk efektivitas pencapaian tujuan.

E-Komik Pendidikan dalam mata pelajaran bahasa indonesia yang telah melewati hasil review para ahli, yaitu ahli isi mata pelajaran Bahasa Indonesia, ahli desain pembelajaran dan ahli media pembelajaran, kemudian produk dapat diujicobakan kepada siswa. Tahap uji coba ini terdiri dari dua tahap yakni uji coba perorangan dan uji coba kelompok kecil. Jika direview kembali validitas dalam uji coba perorangan mendapatkan persentase $94,85 \%$ dengan kualifikasi yang sangat baik. Validasi dalam uji coba 
kelompok kecil memperoleh persentase sebesar 89,99\% dengan kualifikasi baik. Tercapainya dari semua uji coba tersebut, dikarenakan oleh media E-komik ini sangat mudah digunakan oleh siswa serta mendukung belajar siswa secara mandiri, serta gambar dalam E-komik ini sangat menarik perhatian siswa karna gambar dari karakter tersebut bernuansakan pendidikan. Sejalan dengan pendapat Gagne dan Briggs ( dalam Arsyad, 2015) menyatakan bahwa "secara implisit mengatakan bahwa media pembelajaran merupakan alat yang secara fisik digunakan untuk menyampaikan isi materi pembelajaran, yang terdiri dari antara lain buku, tape recorder, kamera, kaset, video recorder, film, televise, slide (gambar bingkai), foto, grafik, dan computer". Dengan kata lain, media merupakan suatu komponen dari sumber belajar, bahan belajar atau wahana fisik yang terdapat materi pembelajaran di lingkungan siswa yang dapat merangsang siswa untuk belajar.

\section{SIMPULAN}

Simpulan dari penelitian ini yaitu: (1) rancang bangun media e-komik pendidikan ini dikembangkan menggunakan model pengembangan ADDIE yaitu: (a) tahap analisis (analysis), (b) tahap desain (design), (c) tahap pengembangan (development), (d) tahap implemetasi (implementation), dan (e) tahap evaluasi (evaluation). (2) Agar dapat digunakan untuk menunjang proses pembelajaran maka media media e-komik harus melewati tahap uji vaidasi yang terdiri dari uji validasi ahli (ahli isi, ahli media, ahli desain) serta uji coba produk (uji perorangan, dan uji kelompok kecil) yang mana ketiga ahli memberikan penilaian sangat baik (valid) serta respon siswa subjek siswa perorangan dan kelompok kecil yang tergolong sangat baik (valid), dengan tetap melakukan revisi sesuai dengan masukan, komentar, dan saran. Berdasarkan hasil penilaian tersebut sehingga media e-komik ini layak digunakan untuk membantu siswa dalam belajar pada pembelajaran Bahasa Indonesia siswa kelas V di SD Negeri 7 Kampung Baru.

\section{DAFTAR PUSTAKA}

Agung, A. A. G. (2017). Buku Ajar Metodologi Penelitian. Yogyakarta: Aditya Media.

Aprilia, N. D. (2019). pengembangan media buku bergambar jombang. Jurnal Pendidikan Bahasa \& Sastra Indonesia, 7(3), 66-82.

Arsanti, M. (2005). Pengembangan Bahan Ajar Mata Kuliah Penulisan Kreatif Bermuatan Nilai-Nilai Pendidikan Karakter Religius Bagi Mahasiswa Prodi PBSI , FKIP , UNISSULA. Jurnal Kredo, 1(2599-316), 71-90.

Arsyad, N. (2015). Penerapan Pendekatan Pembelajaran Poe (Predict-Observe-Explain) Untuk Meningkatkan Kemampuan Berpikir Kreatif Siswa Kelas Xi Ipa-1 Sman 22 Makassar. Jurnal Daya Matematis, 3(1), 51-62.

Budiarti, W. N., dan Haryanto, H. (2016). Pengembangan Media Komik Untuk Meningkatkan Motivasi Belajar Dan Keterampilan Membaca Pemahaman Siswa Kelas Iv. Jurnal Prima Edukasia, 4(2), 233.

Daryanto. (2013). Media Pembelajaran Peranannya sangat Penting dalam Mencapai Tujuan Pembelajaran. Yogyakarta: Gava Media.

Sukayanti., dkk. (2018). Pengembangan Blended Learning Tipe Flipped Classroom Pada Mata Pelajaran Seni Budaya Kelas XI. Jurnal Edutech Undiksha, 6(1), 134-146. 
Jovanovski, D. I. B., dkk. (2019). The Impact of Industry 4.0 on The Competitiveness of Smes. International Scientific Journal "Industry 4.0," 255(5), 250-255.

Lase, D. (2019). Pendidikan di Era Revolusi Industri 4.0. SUNDERMANN: Jurnal Ilmiah Teologi, Pendidikan, Sains, Humaniora Dan Kebudayaan, 1(1), 28-43.

Lestari, D. I., dan Projosantoso, A. K. (2016). Pengembangan media komik IPA model PBL untuk meningkatkan kemampuan berfikir analitis dan sikap ilmiah. Jurnal Inovasi Pendidikan IPA, 2(2), 145-155.

Listiyani, I. M., dan Widayati, A. (2012). Pengembangan Komik Sebagai Media Pembelajaran Akuntansi Pada Kompetensi Dasar Persamaan Dasar Akuntansi Untu SIswa SMA Kelas IX. Jurnal Pendidikan Akuntansi Indonesia, X(2), 80-94.

Mahadewi, L. P. P. dan Sukmana, A. I. W. I. Y. (2015). Text-Based Programming: Konsep Dasar \& Aplikasi Pengembangan Produk Pendidikan. Yogyakarta: Graha Ilmu.

Maslahah, W., dan Rofiah, L. (2019). Pengembangan Bahan Ajar (Modul) Sejarah Indonesia Berbasis Candi-Candi Di Blitar Untuk Meningkatkan Kesadaran Sejarah. Agastya: Jurnal Sejarah Dan Pembelajarannya, 9(1), 32.

Prastowo, A. (2012). Panduan Kreatif Membuat bahan Ajar. Yogyakarta: Diva Press.

Prastya, D. (2015). Pengembangan Multimedia Pembelajaran Interaktif Mata Pelajaran Bahasa Indonesia dengan Model ADDIE untuk Siswa Kelas VII Semester Genap Tahun Ajaran 2014-2015 di SMP Negeri 1 Banjar. E-Journal Edutech Universitas Pendidikan Ganesha Jurusan Teknologi Pendidikan, 3(1), 1-11.

Prawiladilaga, D. S. (2015). Prinsip Desain Pembelajaran (Instruksional Design Principles). Jakarta: Prenadamedia Group.

Purnamasari, H., dkk. (2018). Pengembangan Media Pembelajaran E-Komik Pada Materi Dinamika Rotasi. Prosiding Seminar Nasional Fisika (E-Journal), VII(10), 29-35.

Rifky, H. (2017). Pengembangan media pembelajaran berbasis komik pada mata pelajaran ilmu pengetahuan sosial kelas IV MI Nurul Hidayah Roworejo Negerikaton Pesawaran. Jurnal Pendidikan Dan Pembelajaran Dasar, 4(1), 34-46.

Suartama, I. K. (2010). Pengembangan Multimedia Untuk Meningkatkan Kualitas Pembelajaran Pada Mata Kuliah Media Pembelajaran. Jurnal Pendidikan dan Pengajaran, 43(3), 253-262

Tegeh dan Jampel. (2017). Metode Penelitian Pengembangan. Singaraja: Universitas Pendidikan Ganesha.

Tegeh, I. M., dan Kirna, I. M. (2013). Pengembangan Bahan Ajar Metode Penelitian Pendidikan Dengan Addie Model. Jurnal Ika, 11(1), 12-26.

Witanta, V. A., dan Inganah, S. (2019). Pengembangan Komik Sebagai Media Pembelajaran Matematikapada Materi Perbandingan Kelas VII Smp. Jurnal Ilmiah Pendidikan Matematika, 1(1), 1-12.

Yogiyatno, W. (2013). Pengembangan Multimedia Interaktif Kompetensi Dasar Mengoperasikan Software Basis Data Untuk SMK Negeri 1 Seyegan. Jurnal Pendidikan Vokasi, 3(3), 391-404. 